\title{
Implementation of early will directives: facilities and difficulties experienced by palliative care teams
}

\author{
Implementação de diretivas antecipadas de vontade: facilidades e \\ dificuldades vivenciadas por equipes de cuidados paliativos \\ Implementación de directivas anticipadas de voluntad: facilidades y \\ dificultades experimentadas por los equipos de cuidados paliativos.
}

\section{Aline Carniato Dalle Nogario ${ }^{a}$ Edison Luiz Devos Barlema \\ Jamila Geri Tomaschewski-Barlem ${ }^{\mathrm{a}}$ \\ Rosemary Silva da Silveira ${ }^{a}$ Silvana Bastos Cogo ${ }^{b}$ Deciane Pintanela de Carvalho ${ }^{a}$}

How to cite this article: Nogario ACD, Barlem ELD, TomaschewskiBarlem JG, Silveira RS, Cogo SB, Carvalho DP. Implementation of early will directives: facilities and difficulties experienced by palliative care teams. Rev Gaúcha Enferm. 2020;41:e20190399. doi: https://doi. org/10.1590/1983-1447.2020.20190399
' Universidade Federal do Rio Grande (FURG), Escola de Enfermagem. Programa de Pós-graduação em Enfermagem. Rio Grande, Rio Grande do Sul, Brasil.

${ }^{\circ}$ Universidade Federal de Santa Maria (UFSM) Departamento de Enfermagem, Programa de Pós-graduação em Enfermagem. Santa Maria, Rio Grande do Sul, Brasil.

\section{ABSTRACT}

Objective: To know the facilities and difficulties the palliative care team professionals experience in the implementation process of advance healthcare directives.

Method: Exploratory-descriptive study with a qualitative approach, involving 51 professionals from seven palliative care teams in the state of Rio Grande do Sul, Brazil. The data were collected between December 2018 and April 2019 and discursive textual analysis was applied. Results: The facilities found were: the approach by the palliative care team; listening and respecting patients' wishes; effective communication between professionals, patients, and family members and resolution of difficult situations. The difficulties reported were: legal issues; the lack of knowledge of professionals about the subject; the lack of institutional protocols; the difficulty in talking about death and the family barrier.

Conclusion: Despite the perceived facilities and difficulties, palliative care professionals intend to work based on the patients' desires and will, aiming to offer dignity in the dying process.

Keywords: Advance directives. Palliative care. Ethics.

\section{RESUMO}

Objetivo: Conhecer as facilidades e dificuldades experimentadas pelos profissionais das equipes de cuidados paliativos no processo de implementação de diretivas antecipadas de vontade.

Método: Estudo exploratório-descritivo com abordagem qualitative envolvendo 51 profissionais de sete equipes de cuidados paliativos do estado do Rio Grande do Sul no Brasil. Os dados foram coletados entre dezembro de 2018 e abril de 2019 e a análise textual discursiva foi aplicada.

Resultados: As facilidades encontradas foram: abordagem da equipe de cuidados paliativos; ouvir e respeitar os desejos dos pacientes; comunicação eficaz entre profissionais, pacientes e familiares e resolução de situações difíceis. As dificuldades relatadas foram: questões legais; falta de conhecimento dos profissionais sobre o assunto; falta de protocolos institucionais; dificuldade em falar sobre a morte e barreira da família.

Conclusão: Os profissionais de cuidados paliativos pretendem trabalhar com base no desejo e na vontade do paciente, visando oferecer dignidade no processo de morrer.

Palavras-chave: Diretivas antecipadas. Cuidados paliativos. Ética.

\section{RESUMEN}

Objetivo: Conocer instalaciones y dificultades que experimentan equipos de cuidados paliativos en proceso de implementación de directivas anticipadas de voluntad.

Método: Estudio exploratorio descriptivo con enfoque cualitativo con 51 profesionales de siete equipos de cuidados paliativos del estado de Rio Grande do Sul en Brasil. Los datos se recopilaron entre diciembre de 2018 y abril de 2019 y se aplicó análisis textual discursivo. Resultados: Las instalaciones encontradas fueron: enfoque del equipo de cuidados paliativos; escuchar y respetar los deseos de pacientes; Comunicación efectiva entre profesionales, pacientes y familiares y resolución de situaciones difíciles. Las dificultades reportadas fueron: asuntos legales; falta de conocimiento de profesionales en el tema; falta de protocolos institucionales; dificultad de hablar sobre muerte y barrera familiar.

Conclusión: A pesar de las dificultades y dificultades percibidas, los profesionales de cuidados paliativos tienen la intención de trabajar con el objetivo de ofrecer dignidad en el proceso de morir.

Palabras clave: Directivas anticipadas. Cuidados paliativos. Ética. 


\section{口INTRODUCTION}

In the early twentieth century, the patients' choices as to how they would like to be treated were ignored in an extremely vertical relationship and the physician was considered the holder of knowledge. In the middle of the same century, however, this relationship gradually became horizontal, based on the principle of patient autonomy ${ }^{(1)}$. The emergence of patient autonomy gave rise to the discussion about the right to die as a counterpoint to the technological advance of medicine, capable of postponing death indefinitely ${ }^{(1)}$.

In the Brazilian context, considering the protection of individual autonomy, in 2012, the Federal Council of Medicine (CFM) published Resolution No. 1995, which provides for Advance Healthcare Directives (AHD), enabling the Brazilian population to express their wishes related to health care, which should override the wishes of their families, respecting the ethical precepts of the Brazilian Medical Ethics Code ${ }^{(2)}$. AHDs are legal in Brazil as, although there is still no legislation on the subject, the constitutional principles and the support of the medical and nursing codes of ethics should be taken into account.

AHDs are a kind of document in which the patient expresses his will. Two types exist: living will (LW) and power of attorney $(\mathrm{PA})^{(3)}$. LW is the document that represents the patients' wishes, where their choices are recorded regarding the procedures they would or would not like to undergo if they experience the moment when they are unable to make decisions ${ }^{(4)}$. The PA, then, involves appointing a third party to direct decisions regarding medical treatment when the patient is unable to in the long term ${ }^{(3)}$.

The inclusion of AHD in care enables a different perception of death and contributes to the non-use of obstinate healing practices, as a possibility of accomplishing the wishes the patient had previously manifested when still able to make decisions ${ }^{(5)}$. In this context, palliative care (PC) emerges, which is based on the principles of beneficence, non-maleficence and patient autonomy, aiming for quality of life and human dignity in finiteness, death, and mourning ${ }^{(6)}$.

The World Health Organization (WHO) definition conceptualizes PC as an approach aimed at improving the quality of life of patients (adults and children) and family members who experience problems deriving from life-threatening diseases, preventing and relieving suffering and pain, considering the individuals in their physical, psychosocial and spiritual dimensions ${ }^{(7)}$.

In Brazil, Resolution No. 41 was approved on October $31^{\text {st }}, 2018$, setting the organizational guidelines of PC in the Unified Health System (SUS) and regulating its provision at all levels of health care, whether basic, home-based, outpatient, emergency and hospital-based care ${ }^{(8)}$. In Rio Grande do Sul (RS), on October 31 1 st 2019, Law No. 15.277 established the State Policy of PC, which aims at comprehensive health care for people facing life-threatening diseases ${ }^{(9)}$

AHDs and PC are related in patient care due to the common effort to ensure a dignified death, permeated by respect for their autonomy. In Brazil, in 2011, there were 81 registered AHDs, which increased to 205 in $2012^{(10)}$ The state of RS ranked second in the number of AHDs recorded between 2004 and 2018, with 551 AHDs and, only in 2017, 83 AHDs were recorded ${ }^{(10)}$.

Given this, the question is: what are the facilities and difficulties experienced by palliative care teams in the implementation of advance directives of patients? Therefore, the objective of the study was to know the facilities and difficulties experienced by palliative care teams in the process of implementation of advance directives of will.

\section{METHOD}

This is a descriptive and exploratory study with a qualitative approach. A total of 51 workers were included, namely: physicians, nursing technicians, physical therapists, speech therapists, social workers, religious assistants, occupational therapists, nutritionists, dentists, psychologists, and pharmacists working for at least three months in the palliative care services of seven hospitals in Rio Grande do Sul, Brazil. Those on vacation or leave during the period of data collection were excluded.

The participating institutions were public or philanthropic hospitals listed on the website of Academia Nacional de Cuidados Paliativos (ANCP) [National Academy of Palliative Care] in 2018 located in Pelotas, Santa Maria, Passo Fundo or Sapucaia do Sul while three of which were in Porto Alegre.

The coordinators of the PC teams were asked for the professionals' e-mails to send the invitation to participate in the study and the free and informed consent form. Data collection took place between December 2018 and April 2019. The semi-structured data collection tool created in Google Forms allowed the participants to type their answers, containing open questions to help and identify the study participant (professional category, length of professional experience and length of professional experience in $P C$ ); service characteristics (institution, team composition and type of service offered) and, finally, questions regarding the implementation of the AHDs (facilities and difficulties).

The data collection instrument was elaborated in the semi-structured form, containing questions to characterize the services (institution, length of experience at the service, professionals who are part of the team, service characteristics); 
identification of research subjects (professional category, length of professional experience, length of professional experience in $\mathrm{PC}$ ) and open questions regarding the implementation of AHDs in the service (implementation process, facilities and difficulties encountered, professionals involved, conduct of different professional categories).

The data were analyzed through discursive textual analysis, respecting its four stages: unitization, categorization, capturing of the new that emerges and, finally, the self-organized process, which establishes the creation of a new understanding of the proposed theme ${ }^{(11)}$ Aiming to meet the proposed objective, two a priori categories were established in advance, one related to the facilities in the implementation of the advanced healthcare directives; the other related to the difficulties in the implementation process of the advance healthcare directives.

The study complied with all the precepts regarding ethics in research involving human beings, according to Ministry of Health Resolution No. 466/2012, and was only started after the approval of the local Ethics Committee under opinion 196/2018 and the Ethics Committees of the participating institutions through Plataforma Brazil.

In order to preserve the identity of the study participants, the institutions were named by letters ( $A, B, C, D, E, F$, and $G$ ) and professionals by numbers according to the professional category (1-nurse, 2 -physician, 3-nursing technician, 4-psychologist, 5-nutritionist, 6-speech therapist, 7-occupational therapist, 8-physiotherapist, 9-social worker, 10-dentist, 11-religious assistant and 12-pharmacist).

\section{RESULTS AND DISCUSSION}

Seven PC teams working in RS with different types of activities participated in the study, as follows: one team working in a specific $P C$ unit; a team with expertise as consultants and at a specific PC service; two teams working as consultants, in outpatient care, as itinerant teams and in specific PC beds and three teams working exclusively as consultants.

All teams consist of physicians and nurses; psychologists, physiotherapists, and social workers participate in six teams; nutritionists and religious assistants in five teams; four teams include pharmacists; three teams nursing technicians and two teams speech therapists, occupational therapists and dentists.

In total, out of 98 professionals, 51 participated in the study, being 37 female and 14 male, with professional experience ranging from 2 to 44 years. Regarding $P C$, the length of experience ranged from six months to 32 years and, in vocational training, 12 stated that they had taken a training course and eight a specialization course in PC. To know the experiences of $\mathrm{PC}$ professionals in the implementation process of patients' advance healthcare directives, the results were organized into two categories: facilities and difficulties.

\section{Facilities in the implementation process of advance healthcare directives}

The PC teams stressed the importance of AHDs as a way of respecting patients' autonomy and offering dignity in the process of imminent finiteness. According to the study participants' reports, regarding the facilities in the implementation process of the AHDs, the following were recognized: the PC team's approach of the AHDs; listening and respect for the patients' wishes; effective communication among professionals, patients, and family members; and solving difficult situations.

The professionals reported that the PC team's approach of the AHDs allows patients to express their wishes with a greater guarantee of fulfillment, corroborated by the situations of difficult decisions with advance care planning and safety in the conduct of specific cases involving patients and families. The AHDs allow a more dignified experience of the dying process:

The ease to implement the advance directives was after the establishment of palliative care in the institution, due to the greater safety to conduct the specific cases (B.1.2)

The staff is more relaxed in sharing decisions with the patient and family, and also because of a defined care plan (D.4.1)

Greater chance of patients having their will accomplished (E.2.2)

Discussing end-of-life care is a significant challenge faced by health workers because one of the barriers that emerge and postpone discussions about care options is the fact that patients are prevented from taking part in the decision-making process ${ }^{(12-13)}$. Palliative care workers intend to enable patients to die with dignity so that patients are autonomous to make decisions concerning life-prolonging procedures ${ }^{(14)}$. Therefore, to change such a context, advance directives adopted by PC teams have been efficacious to meet the wishes and desires of patients.

The professionals'listening and acceptance favor respect for the bioethical principles based on the patient's contextualization as the protagonist of his care. It was mentioned that the PC team develops its work based on listening to the patients as a way to detect their needs and understand the wishes they expressed: 
Listening to the patients' wishes (C.8.1)

Facility to respect bioethical principles and the patients' desires (B.2.1)

The patient's understanding as to participating in decisions about himself (E.9.1)

The study participants reported that they consider the patients as the protagonists of their decisions and offering warm listening, respecting their fears and anxieties, driving the approach of the AHDs according to their understanding of their health condition and broadening the possibility of understanding the manifested desires. The practice of informing about the diagnosis and evolution of the disease enables decision making, considering the patients' values and preferences ${ }^{(15)}$.

Effective communication among professionals, patients and family members is a facilitator in the implementation process of AHDs due to these subjects' involvement in the dialogue and in the sensitive perception of the patients' need to experience their dying process in the best possible way, which facilitates the family's understanding and acceptance, bringing comfort in view of the required decisions:

The patients can be assured that their decision will be respected and the family members are comfortable making important decisions (D.2.3)

Acceptance of the family and the care teams (F.2.1)

Contradictions may permeate communication processes established among stakeholders if health workers do not offer the possibility to address end-of-life issues or the option to establish advance directives, revealing a lack of communication between physicians, nurses, and patients ${ }^{(16)}$. In this study, however, effective communication between workers, patients, and families, was mentioned as a way to enable the establishment of advance directives, in which care is planned in such a way that future treatment and end-of-life decisions are based on the patients' expressed desires ${ }^{(15)}$, confirming dialogue can be effectively implemented among all those involved.

The experience of the dying process entails unexpected situations the subjects involved need to face. The resolution of difficult situations, as well as the search for solutions, can contribute and facilitate the implementation process of AHDs, enabling advance care planning and positioning of the health institution in favor of the advocacy for patients'rights:

Avoid doubts in care when complications occur (E. 1.1)

Facility would be that the institution is organized and agrees that the patient's opinion and desire come first (F.1.1)
Reduce the distress of medical clinical residents in decision making on patients' clinical complications (A.2.1)

The ability to resolve difficult situations was reported by this study's participants as a facilitator in the implementation of advance directives, as a document that legally supports health workers, as well as patients, when facing complications and decisions involving conflicts ${ }^{(17-18)}$. This subject needs to be discussed in Brazil, considering the ethical conflicts that permeate procedures intended to respond to a terminal condition ${ }^{(18)}$.

\section{Difficulties in the implementation process of advance healthcare directives}

The approach and subsequent implementation of AHDs can be permeated by the confrontation with barriers that make it difficult to meet the patients' desires and wishes. The difficulties found in the study are permeated by the Brazilian jurisdiction, by the inexistent institutional protocols, by the difficulty in discussing the theme with professionals who are not part of the PC team and family members who are generally unaware of AHDs, as well as the incomprehension of human finiteness as a natural process of life.

The PC teams participating in the study reported that the difficulties in the implementation process of the AHDs in their context are: legal issues, the professionals' lack of knowledge on the subject, lack of institutional protocols, difficulty in talking about death and the family barrier.

The discussion about the regularization of the AHDs is permeated by the lack of a current law in Brazil that regulates and guides its practice. Although there is a resolution that regulates it in the context of medicine, many professionals are still unaware of its concept and objectives, which may contribute directly to the fear of legal punishment:

\section{The fact that the document has legal enforceability but is not a law yet, which makes it difficult for some profes- sionals to accept it (A.2.1) \\ Some professionals' lack of knowledge, combined with the fear of providing care based on shared deci- sion-making and the risk of litigation in family conflict situations (C.2.2)}

There is no law in Brazil regulating advance directives, though projects are being discussed in the Senate to regulate them. It is worth noting that since 2012 medical practice has been supported by resolution No. 1995, which acknowledges advance directives as a way to record and honor the expressed wills of patients ${ }^{(2)}$. 
The discussion regarding end-of-life care in line with life-prolonging treatments may clash with workers' beliefs and take them out of their comfort zone ${ }^{(14)}$, a situation that is corroborated by this study in which the staff is not aware of the legal nature of advance directives and become afraid of punishment or lawsuits on the part of families, and as a consequence, work against the wishes of patients.

The professionals reported that the care team professionals'lack of knowledge on the palliative care philosophy and its relation with the AHDs implies greater resistance to the fulfillment of patients' wishes, making their implementation difficult, especially in institutions that do not have PC services.

That they arefulfilled/attended by other health professionals due to prejudice/personal beliefs and ignorance (C.1.1) The difficulty is that there is still a lot of resistance from the medical teams towards the directives and also towards the palliative theme, so the biggest difficulty is the physicians' acceptance (D.9.1)

The PC teams mentioned the care professionals' lack of knowledge on the palliative philosophy as a difficulty in the implementation of the AHDs, due to the damaged relationship established between the PC team and the care team, also permeated by the western culture in denying death and seeking cure incessantly. The dialogue about end-oflife care stands out as a challenge health professionals face, and further delaying these conversations with the patients disables them from participating in decisions to be made about their health condition ${ }^{(12)}$. Thus, the palliative teams seek to recognize the patients as the protagonist of their care, enabling them to discuss their preferences when assisted by care teams.

The lack of institutional protocols that regulate and direct the approach of the AHDs acts as an obstacle in its implementation, as professionals act based on their knowledge, distancing the interaction with the patient from the care process. Also, the professionals sometimes disrespect the patient's previous request due to fear of legal implications, as the culture of our society is rooted in the paradigm that letting a patient die can be perceived as negligence:

\section{Some hospital staffmembers on duty are unaware of the guidelines and do not respect the measures described in the medical record (A.2.1) \\ Communication between hospital staff to respect the patient's wishes in case of emergency [...] (C.8.1) \\ Let all professionals read and respect the advance health- care directives (E.12.1)}

\section{Containing the urge to take additional measures out of a sense of neglect (F.2.1)}

The lack of institutional protocols that guide the registration of AHDs makes it impossible for all professionals involved in care to get access to the desires and will the patients expressed in advance, especially when the care is provided by professionals who are unaware of their health context. Registering the AHD in the medical record was mentioned as standard conduct among the PC teams in this study. Therefore, it is emphasized that the registers should be accessible to all professionals involved, regardless of the place or time of care ${ }^{(15)}$

The acceptance of death as an inherent process in human life is a matter of difficult discussion in our society, based on paternalistic medical practice and the relentless pursuit to maintain life at all cost, which directly influences the suffering caused to the patient when submitted to stubborn practices in search of a cure that is no longer possible:

Lack of "affective availability" to be able to accept the finiteness of life and talk about the end of life with the patients. The cultural barrier: Latinos can't stand talking about death (A.2.2)

When religious confession leads to cure and especially when cure is associated with faith. So talking of no cure or death is a synonym of weakness (A.11.1)

Death causes families to experience intense suffering, which may be permeated by a feeling of loss and doubts that lead families to question what could have been done in terms of treatments to avoid it. PC workers report such factors, especially the resistance of families to accept, allow, and understand the death of a loved one.

Giving a voice to family members is essential when patients are incapacitated ${ }^{(5)}$, however, appointing a family member or even a friend to make decisions may lead to issues permeated by affectivity, hindering the process ${ }^{(16)}$. Conflicts concerned with advance directives are challenging to handle because these are usually closely linked to values, beliefs, and the experiences of different stakeholders ${ }^{(19)}$.

One of the difficulties faced in the process of implementing AHDs is the family's resistance to accepting and allowing the death of a patient, which is permeated by the shallow or even nonexistent discussion about human finiteness. The conflicts experienced concern the understanding that the patients should not know information about their prognosis, the difficulty in respecting individual autonomy and the different opinions that emerge in the family group: 
Family members' difficulty to respect patients' autonomy regarding their choices (C. 1.2)

When the patient is no longer lucid or numb and the family's opinions are divided (F.9.1)

Family members often make it difficult because they usually do not want the patient to know the prognosis (G.2.1)

In the context of AHDs, one of the barriers faced in their approach is the reluctance of health professionals in caring for patients in cases of imminent death ${ }^{(17)}$. The study participants mentioned that the care team professionals hinder the implementation process of AHDs when they deny human finiteness and perform care that will not modify the course of the disease, a factor that may be associated with the Western culture of denial of death, which makes the patients and their family members suffer due to the search for conducts that prolong life, even in the face of a disease that has no prospect of cure ${ }^{(20)}$

\section{GONCLUSION}

The palliative philosophy, based on providing patients with quality of life in their active dying process, allows the PC team professionals to serve as facilitators in the implementation of the AHDs, keeping in mind that care is not planned to avoid death, but to pursue human dignity and finiteness without pain and suffering.

In the approach of AHDs, listening and respecting the patients' wishes act as guidelines for the professionals' conduct as, to the extent that the patients expose their wishes and doubts, the professionals plan care and approach according to the limits of their understanding. Consequently, establishing the bond of trust enables effective communication with family members as well.

Professionals familiar with patients' wishes and desires perceive the resolution of difficult situations as a facilitator in the implementation of AHDs. The path taken from the approach to its effective implementation does not necessarily prevent conflicts from arising, but directs the conduct of professionals, facilitating decision making in situations of complications. Regarding the difficulties the professionals face, due to the lack of institutional protocols, non-palliative teams may feel helpless, corroborating care practices aimed at escaping from conflicts and the protection of those who care even if, consequently, the patient experiences avoidable suffering.

The implementation of AHDs involves the commitment of the health team and requires a discussion about the theme as a way to find the support that enables the professionals to understand its benefits for the patient and people involved in the experience of death.

The study revealed that, in the current context of PC teams, the main need among patients, family members, and professionals, whether in the family or academic environment, is to dialogue about the understanding that death is part of the life process. The approach and subsequent implementation of AHDs require individuals who understand that allowing death while respecting the desires and wishes of patients is a way to ensure the exercise of autonomy, enabling human dignity through the experience of reducing pain and suffering.

\section{REFERENCES}

1. Dadalto L. Living Will's History: understanding the past and reflecting about the present.MirabiliaMedicinæ.2015 [cited2019Apr 12];4(1):23-42.Availablefrom: https://www.revistamirabilia.com/sites/default/files/medicinae/pdfs/med 2015-01-03.pdf

2. Conselho Federal de Medicina (BR). Resolução no. 1.995, de 9 de agosto de 2012. Dispõe sobre as diretivas antecipadas de vontade dos pacientes. Diário Oficial da União da República Federativa do Brasil. 2012 ago 31;149(170 Seção 1):269.

3. Dadalto L, Tupinambás U, Greco DB. Diretivas antecipadas de vontade: um modelo brasileiro. Rev Bioet. 2013;21(3):463-76. doi: https://doi.org/10.1590/ S1983-80422013000300011

4. Piropô US, Damascceno RO, Rosa RS, Sena ELS, Yarid SD, Boery RNSO. [Correlation of living will, bioethics, professional activity and patient autonomy]. Rev Salud Pública.2018;20 (4):505-10. Portuguese. doi: https://doi.org/10.15446/rsap.v 20n4.65009

5. Cogo SB, Lunardi VL, Quintana AM, Girardon-Perlini NMO, Silveira RS. Challenges to implementation of advance directives of will in hospital practice. Rev Bras Enferm. 2016;69(6):969-76. doi: https://doi.org/10.1590/ 0034-7167-2016-0085

6. Matsumoto DY. Cuidados paliativos: conceito, fundamentos e princípios. In: Carvalho RT, Parsons HA, organizadores. Manual de cuidados paliativos. $2^{\text {a }}$ ed. Rio de Janeiro: Diagraphic; 2012. p.23-30.

7. World Health Organization (CH) [Internet]. Geneva: WH0; c2017-2020 [cited 2020 Jan 2]. Palliative care; [about 1 screen]. Available from: https://www.who. int/news-room/fact-sheets/detail/palliative-care

8. Ministério da Saúde (BR). Comissão Intergestores Tripartite. Resolução no 41, de 31 de outubro de 2018. Dispõe sobre as diretrizes para a organização dos cuidados paliativos, à luz dos cuidados continuados integrados, no âmbito Sistema Único de Saúde. Diário Oficial da União. 2018 nov 23;155(225 Seção 1):276.

9. Governo do Estado do Rio Grande do Sul (BR). Lei n. 15.277, de 31 de janeiro de 2019. Institui a política estadual de cuidados paliativos e dá outras providências. Diário Oficial do Estado [do Rio Grande do Sul]. 2019 jan 31;23(3).

10. Central Notarial de Serviços Eletrônicos Compartilhados (BR). Relatório estatístico acerca de atos inerentes a diretivas antecipadas de vontade 2004/ 2018. [mensagem pessoal]. Mensagem recebida por: censec@notariado.org.br em 12 mar 2018.

11. Moraes R, Galiazzi MC. Análise textual discursiva. 2 ed. ljuí: Editora Unijuí; 2013. 
12. Bélanger E, Rodríguez C, Groleau D, Légaré F, Macdonald ME, Marchand R. Initiating decision-making conversations in palliative care: an ethnographic discourse analysis. BMC Palliative Care. 2014;13:63. doi: https://doi.org/10. 1186/1472-684X-13-63

13. Vleminck A, Houtekkier D, Stichele RV, Pardon K. Development of a complex intervention to support the initiation of advance care planning by general practitioners in patients at risk of deteriorating or dying: a phase 0-1 study. BMC Palliative Care. 2016;15:17. doi: https://doi.org/10.1186/s12 904-016-0091-X

14. Hassegawa LCU, Rubira MC, Vieira SM, Rubira APA, Katsuragawa TH, Galoo $J$, et al. Approaches and reflexions on advance healthcare directives in Brazil. Rev Bras Enferm. 2019;72(1):266-75. doi: https://doi.org/10.1590/0034-71 67-2018-0347

15. Kok M, Werff GFMV, Geerling II, Ruivenkamp J, GroothoffW, Velden AWGV et al. Feasibility of hospital-initiated nonfacilitator assisted advance care planning documentation for patients with palliative care needs. BMC Palliative Care. 2018;17(7). doi: https://doi.org/10.1186/s12904-018-0331-3
16. Scottini MA, Siqueira JE, Moritz RD. Patient's rights to advanced directives. Rev Bioét. 2018;26(3):440-50. doi: https://doi.org/10.1590/1983-80422018 263264

17. Monteiro RSF, Junior AGS. Advance directive: historical course in Latin America. Rev Bioét. 2019;27(1):86-97. doi: https://doi.org/10.1590/1983-80 422019271290

18. Cogo SB, Lunardi VL. Advance directives: a documentary analysis in the global context. Texto Contexto Enferm. 2018;27(3):e1880014. doi: https://doi.org/ 10.1590/0104-070720180001880014

19. Saioron I, Ramos FRS, Schneider DG, Silveira RS, Silveira LR. Advance directives of will: nurses' perceptions of benefits and new demands. Esc Anna Nery. 2017;21(4):e20170100. doi: https://doi.org/10.1590/2177-946 5-ean-2017-0100

20. Barbosa RMS, Cabana MCFL. Os cuidados paliativos e a relação da equipe de saúde com o paciente sem possibilidades de cura. Psicologado. 2018 [cited 2019 Apr 5]:3. Available from: https://psicologado.com.br/atuacao/psicologiahospitalar/os-cuidados-paliativos-e-a-relacao-da-equipe-de-saude-com-0paciente-sem-possibilidade-de-cura

\section{- Corresponding author:}

Aline Carniato Dalle Nogario

E-mail:alinenogario@gmail.com

\section{Editor-in-chief:}

Maria da Graça Oliveira Crossetti 